\title{
Modeling Groundwater Flow System of a Drainage Basin in the Basement Complex Environment of Southwestern Nigera
}

\author{
Akinwumiju, A. S. ${ }^{a}$ and Olorunfemi, M. O. ${ }^{b}$ \\ ${ }^{a}$ Department of Remote Sensing and GIS, Federal University of Technology, Akure, Nigeria. \\ ojhakin@yahoo.com \\ ${ }^{b}$ Department of Geology, Obafemi Awolowo University, Ile-Ife, Nigeria
}

\begin{abstract}
This study attempted to model the groundwater flow system of a drainage basin within the Basement Complex environment of Southwestern Nigeria. Four groundwater models were derived from Vertical Electrical Sounding (VES) Data, remotely sensed data, geological information (hydrolineaments and lithology) and borehole data. Subsequently, two sub-surface (local and regional) flow systems were delineated in the study area. While the local flow system is controlled by surface topography, the regional flow system is controlled by the networks of intermediate and deep seated faults/fractures. The local flow system is characterized by convergence, divergence, inflow and outflow in places, while the regional flow system is dominated by NNE-SSW and W-E flow directions. Minor flow directions include NNW-SSE and E-W with possible linkages to the main flow-paths. The NNE-SSW regional flow system is a double open ended flow system with possible linkage to the Niger Trough. The W-E regional flow system is a single open ended system that originates within the study area (with possible linkage to the NNE-SSW regional flow system) and extends to Ikogosi in the adjoining drainage basin. Thus, the groundwater drainage basin of the study area is much larger and extensive than its surface drainage basin. The all year round flowing (perennial) rivers are linked to groundwater outcrops from faults/fractures and contact zones. Consequently, larger percentage of annual rainwater usually leaves the basin in form of runoff and base flow. Therefore, the basin is categorized as a donor basin but with suspected subsurface water input at its northeastern axis.
\end{abstract}

Keywords: Hydrology, Hydrogeology, Drainage Basin, Water Resources, Groundwater Flow System

\section{Introduction}

Sustainable water resource management requires detailed and comprehensive basin-scale hydrological studies. As a result, much emphasis has been laid on drainage basin as an integrated system where interactions among surface water, groundwater, water resource exploitation and the consequent impact on the ecosystems take place (Zhou and $\mathrm{Li}, 2011)$. Overtime, groundwater modeling has been playing significant role in sustainable water resource management. In particular, groundwater flow modeling has been effective in diverse ways (Zhou and Li, 2011). For example, groundwater flow modeling could be employed to investigate groundwater system dynamics and flow patterns (Mallast et al., 2011); groundwater system response to stress (Wang et al., 2009); groundwater recharge, discharge and aquifer storage processes as well as quantifying optimum aquifer yield (Freeze and Witherspoon, 1967); future anthropogenic impacts on groundwater resources (Oseji, 2010); groundwater development scenarios and alternative policies (Shao et al., 2009). In the same vein, groundwater flow model can serve as supporting planning tools for field investigations (Sun and Johnson, 1994) and as visualization tool for disseminating crucial research findings to the public and decision-makers (Sudicky et al., 1985; Sudicky, 1986).

The rate and direction of groundwater flow within a given medium is controlled by hydraulic gradient, which in turn is a function of the extent of the aquifer system, the location as well as the rate of recharge and discharge (Ying et al., 2008). Aside from the force of gravity induced by topography, geological structures (such as fault and fracture) can influence groundwater flow directions particularly in the basement environment (Orabone, 1997). While topography might be the dominant determinant factor of groundwater flow direction within subsurface relatively homogenous earth materials (such as thick unconsolidated sedimentary layer), geological structures (i.e. fault and fracture) usually dictate groundwater flow pattern in the basement environment (Olorunfemi, 1990; Olorunfemi and Fasuyi, 1993). In some cases, groundwater flow direction might jointly be influenced by both the topography and geological structures (Orabone, 1997; Mallast et al., 2011). However, in the Basement Complex terrain, the influence of topography and geological structures on groundwater flow pattern also depends on the physicochemical characteristics of the bedrocks (Oxtobee and Novakowski, 2002; Sophocleous, 2002; Conant, 2004). For instance, in the fractured terrain of Oak Ridge in Tennessee, USA, Solomon et al. (1992) observed that more than $90 \%$ of the groundwater flowed in the basal region of the weathered profile, discharging into streams without any contact with the fractured rocks. In this case, the nature of the bedrocks favors the dominance of topographic influence on the groundwater flow pattern (Peter and Kirk, 1998). Furthermore, the interactive 
influence of topography and geological structures on groundwater flow pattern is very crucial in delineating groundwater basins. For instance, Tiedeman et al. (1998) observed that groundwater basin of Mirror Lake in New Hampshire, USA was 1.5 times larger than the surface water basin. Just as the surface drainage is controlled by surface topography, a groundwater flow system is also subject to the relief of the bedrocks with possible interference by geological structures. In this case, there is the need to differentiate between the influence of surface topography and bedrock topography on groundwater movement. This is because; surface topography sometimes might not be a true representative of the bedrock topography. Experience has revealed that regional groundwater flow occur within the saprolite as the surface of the bedrocks serve as the planforms (Akinwumiju, 2015).

Groundwater flow pattern could be modeled based on data from field observations (Lacomber, 2000; Herman, 2005; Oseji, 2010). Sometimes, groundwater flow direction could be monitored directly on the site using instrumentations such as Colloidal Borescope (Peter and Kirk, 1998). In most cases, Simulation Models such as MODFLOW are employed to hypothetically model groundwater flow pattern within the subsurface of a given basin (Woessner, 2000; Harbaugh et al., 2002). Groundwater flow pattern could also be modeled by adopting multiple techniques. For example, Mallast et al. (2011) relied on topography and the orientation of hydrolineaments to model the groundwater flow-paths in the Western Catchment of Dead Sea. Furthermore, groundwater flow pattern could also be approached from geophysical perspectives. In this case, geophysical data such as Vertical Electrical Sounding data could be interpreted and analyzed for the purpose of groundwater flow pattern modeling.

This study, therefore, attempted to model the groundwater flow systems of a 6th order drainage basin in the Basement Complex terrain of Southwestern Nigeria. An attempt was made to model groundwater flow pattern based on bedrock topography, hydrolineaments and groundwater head in a Geographic Information System environment. Thereafter, we compared the surface water flow system with the groundwater flow system in terms of area of influence and channel orientations.

\section{Study Objectives}

The specific objectives of this study are to:

1)model the groundwater flow pattern of the basin

2)model the 3-Dimensional basement topography of the study area

3)map and characterize the groundwater flowpaths across the basin

4)model the surface- and groundwater interface within the basin

\subsection{Study Area}

The Osun Drainage Basin lies within $7^{\circ} 35^{\prime}$ and $8^{\circ} 00^{\prime}$ North of the Equator; $4^{\circ} 30^{\prime}$ and $5^{\circ} 10^{\prime}$ East of the Greenwich Meridian; in the undulating Yoruba Plain of Southwestern Nigeria (Figure 1). Osun Catchment $(2,194.59 \mathrm{~km} 2)$ extends from the upland area of Ekiti State to the low-lying area of Osun State, covering 21 Local Government Areas with projected population of 6.2 million as at December, 2014 (Akinwumiju, 2015). The study area is underlain by the Precambrian Basement Complex rocks that are characterized by both foliated and non-foliated rocks such as quartzite/quartz schist, amphibole schist, mica schist, amphibolite, migmatite, porphyritic granite, biotite granite, pegmatite, granite gneiss, banded gneiss and charnockite. Notable geological structures within the study area include Efon Ridge and the Zungeru-Ifewara Faults that dissect the study area (De Swardt, 1953; Elueze, 1977; Boesse and Ocan, 1988; Oluyide, 1988; Odeyemi et al., 1999; Awoyemi et al., 2005). The basin's outcrops are dominated by felsic rocks, comprising quartzite/quartz schist and granitic rocks of varying grades (Akinwumiju, 2015). The low-lying areas of the basin are predominantly underlain by amphibolite and amphibole schist that have been deeply weathered, leading to the occurrence of relatively thick overburden (Akinwumiju, 2015). The eastern axis of the basin is characterized by uplands that are deeply incised by Osun River that drains towards the western axis into Asejire dam in Oyo State (Akinwumiju et al., 2016). Close to the center of the basin, occurs the Effon Ridge that stretches across the basin at NNE-SSW orientation, representing the most prominent surface geological structure within the basin (Akinwumiju, 2015). Another notable surface structure is the NNE-SSW oriented Imo Cuesta that occurs within a relatively low-lying western axis of the basin (Akinwumiju, 2015). This structure is perceived to be an extension of Effon Ridge due to the similarities in their lithology, structural strike and dip as well as hydrocharacteristics. For instance, their (Effon Ridge and Imo Cuesta) geological formations conspicuously dip northeastwards. A syncline was notable at the eastern (upland) axis of the basin, occurring between ridges. Two principal faults dominate the subsurface structures of the basin. The prominent subsurface structures include the northeastern Zungeru-Ifewara faults and the western Iwaraja Trans-current faults (Akinwumiju, 2015; Akinwumiju et al., 2016; Okunubi and Olorunfemi, 2016). Based on orientations, the faults of the basin could be grouped into six viz: NNE-SSW (5o-15o) oriented faults; NE-SW (30o-45o) oriented faults; E-W (75o-90o) oriented faults; W-E (270o-285o) oriented faults; NW-SE (300o-315o) oriented faults and NNW-SSE (345o-360o) oriented faults (Akinwumiju et al., 2016). Annual rainfall is generally high, ranging from $1400 \mathrm{~mm}$ in the eastern axis to as high as $1700 \mathrm{~mm}$ in the western axis. The study area is characterized by four watersheds viz: Effon Ridge, Imo Cuesta, Ekiti Upland and Ikirun Highland. The outcropping of the heavily fissured quartzite/quartz schist on the Effon Ridge and Imo Cuesta makes the two 
watersheds the major recharge areas within the basin. Aquifers of the basin can be broadly grouped into two viz: weathered layer aquifer (occurring within the overburden) and fractured aquifer (confined and unconfined). The weathered layer aquifers occurred mostly within the saprolite and are generally less prosperous. The fractured aquifers constitute the only prolific water bearing strata within the basin but with limited occurrence.

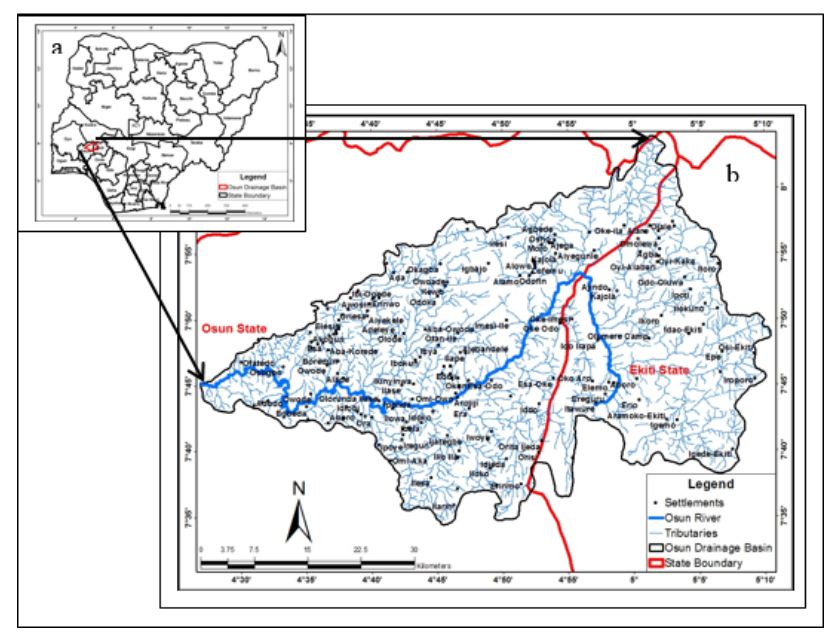

Figure 1: Map of the Study Area showing a): Nigeria's State Boundaries; b): Osun Drainage Basin

\section{Materials and Methods}

Vertical Electrical Sounding data from 497 locations within and around the study area were acquired from multiple sources, including field survey. Hydrogeological data from 162 boreholes were obtained from Rural Water and Environmental Sanitation Agencies (RUWESA) in Osun and Ekiti States, Southwestern Nigeria. SPOT DEM (2012), Spot5 Imagery (2008), and Topographical map (2010) were sourced from the Office of the Surveyor-General of the Federation (OSGOF), Abuja Nigeria. Other ancillary (lithology and hydrolineaments) data were extracted from archives and existing literatures. To model the groundwater flow system of the study area, four methods were adopted. These include: a) automated groundwater modeling procedure (Darcy Flow Analysis), b) automated spatial interpolation and analysis method, c) 3-Dimensional basement topographic modeling and $\mathrm{d}$ ) the manual overlay and analysis procedure. These methods are further described below.

The Darcy Flow Analysis of Groundwater module was adopted to model the flow direction of groundwater within the study area in ArcGIS 10.3 environment. The surface elevation of the wells and the depth to water table were utilized to determine the groundwater head, which was estimated by adopting the following equation:

$\mathrm{Gh}=\mathrm{E}-\mathrm{DWT}$.

Where, Gh is the groundwater head, $\mathrm{E}$ is the surface elevation and DWT is the depth to water table.

Using the groundwater head as input data, Spatial Interpolation module was employed to model Groundwater Flow pattern within the basin in ArcGIS 10.3 environment. In this case, groundwater flows from the region of high groundwater head to the region of low groundwater head. Thus, groundwater flow directions were mapped based on horizontal hydraulic gradients across the basin. The techniques of partial curve matching and computer assisted 1-D forward modeling were employed for the quantitative interpretation of the VES data. Thereafter, overburden thickness was derived from the results of the VES interpretation. This set of information served as the input data for the modeling of overburden vis-à-vis depth to bedrock across the study area. The overburden, as used here, is the totality of the materials (topsoil and weathered basement) above the fresh basement bedrock. The thickness of the regolith overlying the bedrock of the study area was modeled from the interpretation results of Vertical Electrical Sounding (VES) data. The result of the interpretation was imported to ArcGIS 10.3 environment and was utilized (in conjunction with Digital Elevation Model) to generate a $2.5 \mathrm{D}$ gridded image of the bedrock topography of the basin. The terrain grid was transformed into 3D basement topography on Surfer 12 platform. In order to derive the regional flow-paths across the basin, hydrolineaments were superimposed on the piezometric head and topography was followed but general orientation of lineaments was preferred. The output flow-paths were validated with the VES interpretation results. The results of these methods were compared and analyzed in order to model the groundwater flow system of the study area.

\section{Results}

Four different groundwater models (maps) were generated for the study area. These include, the groundwater flow pattern (based on peizometric head analysis), groundwater flow direction (based on Darcy Flow analysis), 3D groundwater flow pattern (based on bedrock topographic modeling) and the derived regional groundwater flow-paths (based on hydrogeologically significant lineaments and geophysical investigations). While the first two models (Figures 3 and 4) portrayed the local flow systems and patterns, the third model (Figure 5) represents the interface between the local flow system and the regional flow system. In this case, as the bedrock topography exerts its influence on the regional groundwater flow system, it also constitutes the gateway through which percolating water seep into the underlying fractures and faults in places within the basin. The fourth model (Figure 6) portrays the regional flow-paths through which groundwater flow in and out of the basin. This model represents the regional groundwater flow system, which is controlled by the network of intermediate and deep seated fractures and faults.

Figure 7 presents the overlay of piezometric head, groundwater flow direction and regional groundwater flow-paths. Analysis suggested the existence of multiple scenarios of groundwater system whereby a given location could be characterized by both local and regional flow systems or either of the systems. Likewise, flow systems might be interconnected or unconnected. However, geophysical investigations indicated interactions between the local flow system and the 
regional flow system in places within the study area where the occurrence of weathered layer/unconfined fractured aquifers were evident. Such aquifers were intercepted in Ilesa-Iwaraja-Iloko Ijesa axis of the basin. Arguably, such interfaces constitute the gateways through which fractures and faults are been fed with water. Thus, the basin's groundwater flow system obviously reflected the combined influence of surface and subsurface topography as well as geological structures. Figure 8 presents the basin's surface and subsurface fluid exchange scenarios. Analysis revealed that river channels are relatively deep and narrow. In most cases, groundwater heads were higher than the channel beds. Results showed that majority of the rivers (ranging from 2nd order to 5th order) incised deeply into the basin's overburden and are predominantly effluent. In this case, the elevations of the river channel planforms (river beds) are lower than the piezometric heads. Thus, rivers receive discharged water from saturated aquifers. These attribute accounts for heavy runoffs as well as prolong peak flow during the wet season across the basin. On the other hand, aquifer recharge from rivers was restricted to sub-basin crests where the elevations of river channel planforms are higher than the piezometric heads. Field investigations confirmed the existence of some perennial rivers that take their sources from trans-current faults and contact zones. Such rivers are common around Effon (ridge) Psalmite Formation and Imo Cuesta. However, Long-term qualitative analysis of hydrological system of the basin indicated that larger percentage of the annual rainfall usually leave the basin as runoff. This could be attributed to relatively low permeability of the overburden and low storativity of the aquifers of the basin.

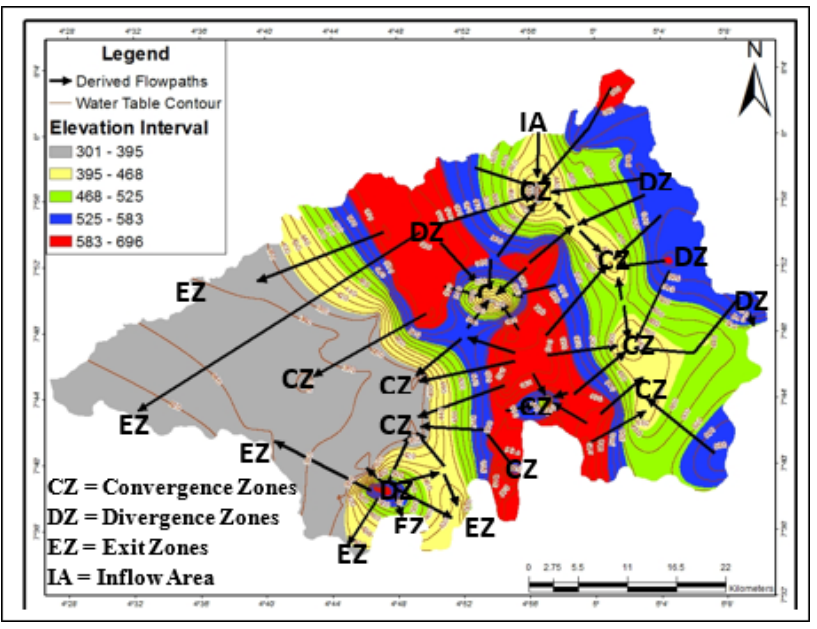

Figure 3: Derived Groundwater Flow-path Map (based on Piezometric Head)

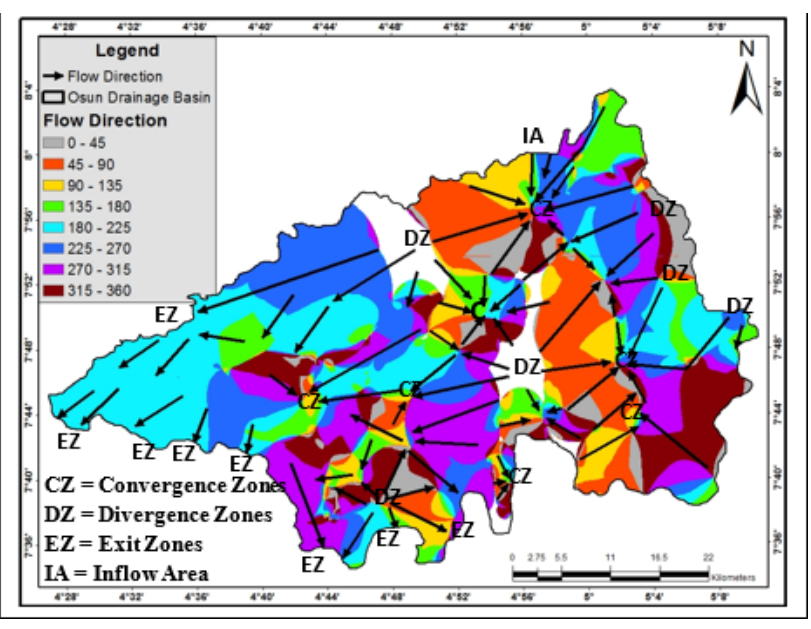

Figure 4: Darcy Flow Model-Derived Groundwater Flow Direction Map

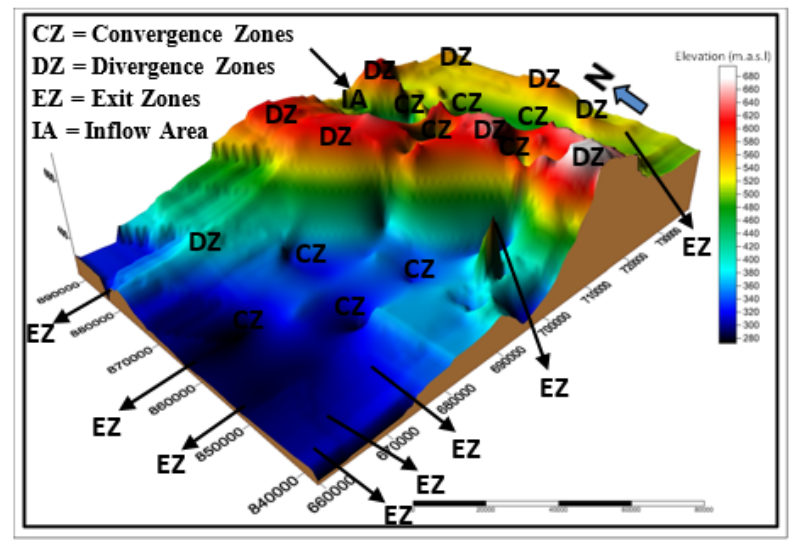

Figure 5: 3-Dimensional Solid Image of the Basement Elevation across the Study Area

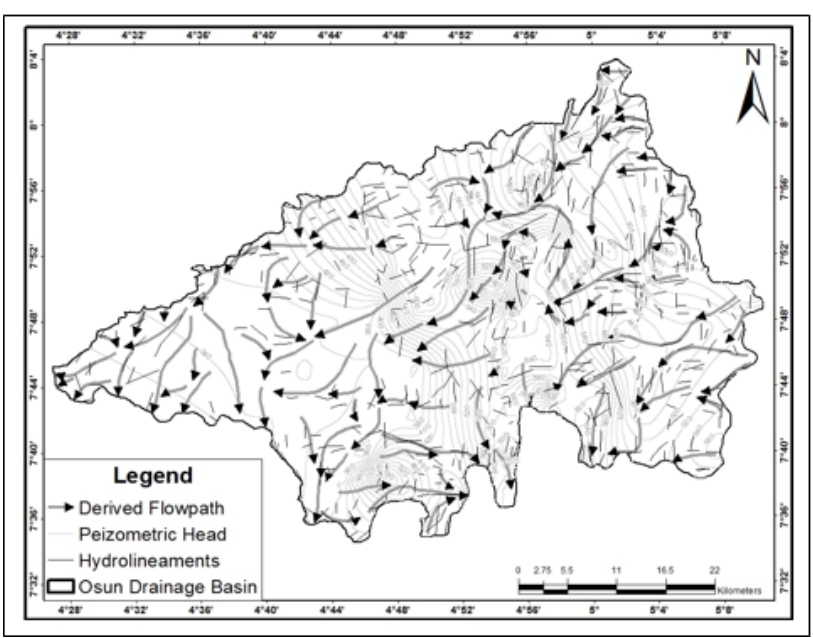

Figure 6: Regional Groundwater Flowpaths 


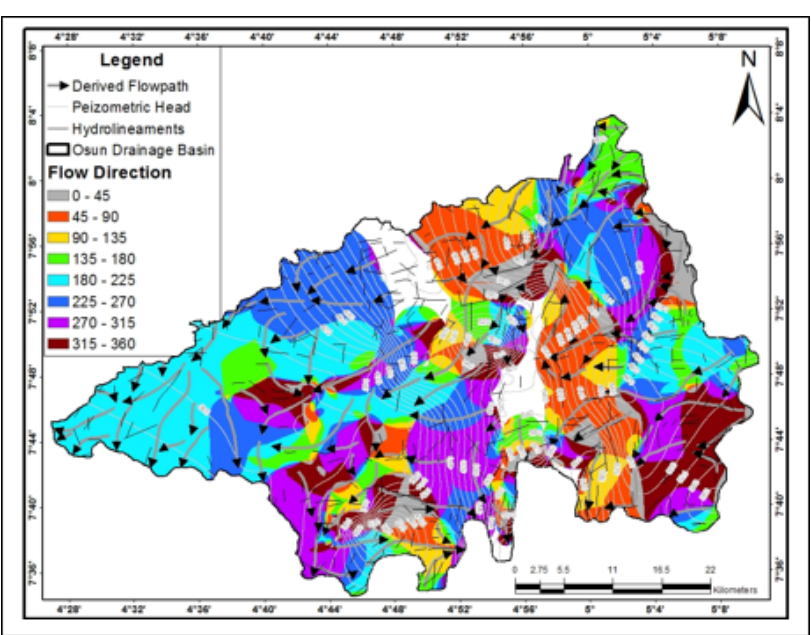

Figure 7: Regional Groundwater Flowpaths

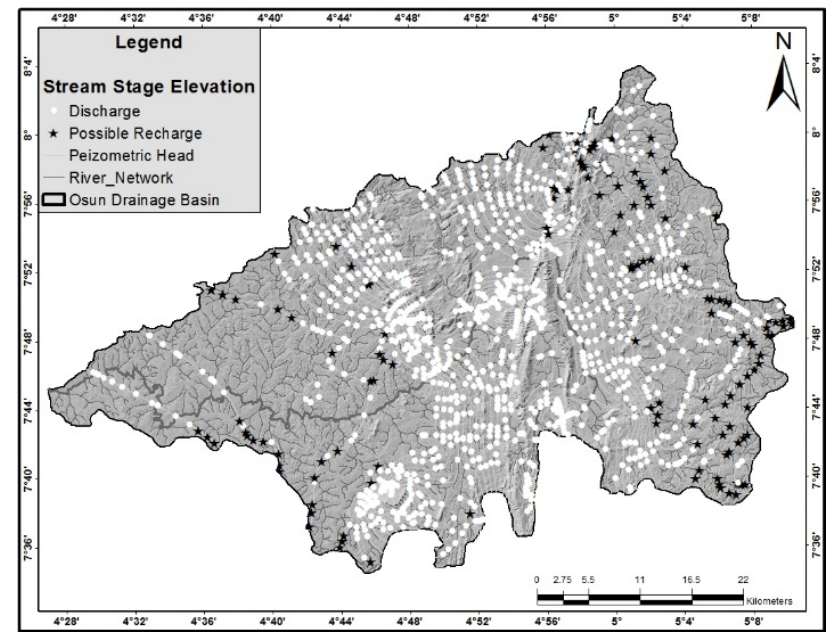

Figure 8: Surface - Subsurface Fluid Exchange Map

\section{Discussion}

Results showed that shallow groundwater flow system is complex but however, interpretable. Observed flow pattern reflected the influence of topography and hydrogeological characteristics of shallow unconfined aquifers of the study area. On the flow pattern map, groundwater convergence zones $(\mathrm{CZ})$, divergence zones (DZ), inflow area (IA) and exit zones (EZ) were conspicuously delineated. At the eastern axis of the study area (covering the upland areas that are mostly situated in Ekiti State), delineated groundwater convergence zones include Itawure area, Aboro-Olumere Camp area, IkoroKajola area, Obasinkin-Aiyegunle area, Efon area and Oke-Odo area (see Figure 1 for the identification of these locations on the map). In the western (low lying area of the study area that falls within the political boundary of Osun State) axis, convergence zones were also suspected in Iwoye-Ijesa, Esa-Odo, Ilase and Ilo-Ijesa. The divergence zones include Igbajo-Otan-Aiyegbaju upland area, Oko Aro-Esa Oke hilly area, Erio Mountain and Imo (Ilesa) cuesta. The groundwater exits (outflow points) concentrate along the southwestern margin of the study area arguably, as a result of the E-W, N-S tilting of the drainage basin. The delineated outflow areas include Otapa, Oke-Ibode, Ilarin-Ijesa, Iwaraja and Ijamo.
Groundwater outlet was also suspected in Dagbolu area at the northern flank of the basin's pore point, suggesting groundwater discharge into the neighboring drainage basin at the northern axis of the study area. Groundwater inflow was suspected at the northeastern axis of the study area around Ora, close to Osun-Ekiti political boundary. This can be attributed to Zungeru-Ifewara mega-faults that dissect the study area. The visual expression of the description given above as presented in Figure 4, displayed the 3-Dimensional image of the basement topography, which portray groundwater flow pattern of the study area with depression zones symbolizing convergence zones and elevated zones representing divergence zones. In the same vein, groundwater inflow and outflow points were obviously delineated.

Groundwater flow-paths were basically controlled by fractures and network of faults that respectively constitute concentrating bowls and conduits for percolating water from the overburden. The major strikes of the flow-paths include the NNE-SSW and W-E with minor orientations of E-W and NNW-SSE. The E-W and NNE-SSW oriented flow-paths are mainly controlled by topography. In this case, there seems to be a relationship between these flow-paths and surface drainage network. The NNE-SSW oriented flow-paths are controlled by Zungeru-Ifewara Faults, which dissect the basin approximately at the center. By far, this set of flow-paths is the most prominent and clearly suggested that the regional groundwater flow system extend beyond the surface hydrological boundary of the basin. In fact, hydrogeological analysis and geophysical investigations clearly identified groundwater inflow and outlet at the northern and southern extremes of Zungeru-Ifewara Mega Faults in the study area. The W-E oriented flowpaths are controlled by the Iwaraja Trans-current Faults that extend from Ilesa (in Osun State) to Ikogosi (in Ekiti State) (Okunubi and Olorunfemi, 2016). Based on geophysical investigations, multiple subsurface flow systems were identified within the fault zones. Thus, the deeply incised W-E oriented Iwaraja Trans-current Faults also control a regional flow system that is suspected to have extended to Ikogosi in Ekiti State. Moreover, two major flow systems have been identified in the study area. The first constitute the local flow systems that are controlled by horizontal and vertical hydraulic gradients. And the second is the regional flow systems that are controlled by the two major networks of faults viz: Zungeru-Ifewara Mega Faults and Iwaraja Trans-current Faults. While the local flow systems seem to be complex and characterized by multiple convergent and divergent patterns of flow direction, the regional flow system is dominated by NNE-SSW and W-E flow directions. It was observed that shallow groundwater discharge was pronounced at the western axis of the basin (around Osogbo) as a result of relatively high transmissivity within the shallow aquifers. Thus, bulk of the annual rainwater input usually leave the basin in form of surface runoff and groundwater discharge, hence the abundance of water resources within the adjoining receptor basins (e.g. Ilobu and Ede). 


\section{Conclusion}

Multi-sourced geospatial data were subjected to four procedures of GIS-based modeling with a view to illustrating, evaluating and analyzing the groundwater flow system of Osun Drainage Basin in the basement environment of Southwestern Nigeria. Consequently, two sub-surface (local and regional) flow systems were identified and delineated in the study area. While the local flow system was observed to be controlled by surface topography and the shallow aquifers' hydrogeologic characteristics, the regional flow system was controlled by the networks of intermediate and deep seated faults/fractures. It was observed that the local flow system was complex and characterized by convergence, divergence, inflow and outflow in places. On the other hand, the regional flow system was dominated by NNESSW and W-E flow directions. Minor flow directions include NNW-SSE and E-W, with possible linkages to the main flow-paths. The NNE-SSW regional flow system was a double open ended flow system believed to have originated from the Niger Trough and dissected the study area, extending to the adjoining lower basin. The $\mathrm{W}-\mathrm{E}$ regional flow system was a single open ended flow system that was adjudged to have originated within the study area (with possible linkage with the NNE-SSW regional flow system) and extend to Ikogosi in Ekiti State. Thus, analysis revealed that the groundwater drainage basin is much larger and extensive than its surface drainage basin. Results showed that rivers of the basin are mostly effluent but with the existence of few rivers around sub-basins' crests that are influent. The all year round flowing (perennial) rivers were linked to groundwater outcrops from faults/fractures and contact zones. Consequently, larger percentage of annual rainwater usually leaves the basin in form of runoff (in wet season) and base flow (in dry season). Therefore, the basin was categorized as a donor basin but with suspected subsurface water input at the northeastern axis of the basin. In conclusion, this study demonstrated the advantage of integrating multi-source geo-scientific data such as remote sensing, hydrogeological, geological and geophysical data for groundwater system studies.

\section{References}

Akinwumiju, A. S. (2015). GIS-Based Integrated Approach to Groundwater Potential Assessment of Osun Drainage Basin, Southwestern Nigeria. An Unpublished Ph.D. Thesis Submitted to the Institute of Ecology and Environmental Studies, Obafemi Awolowo University, Ile-Ife, Nigeria. 316pp

Akinwumiju, A. S., Olorunfemi, M. O. and Afolabi, O. (2016). Automated Lineament Mapping from Remotely Sensed Data: Case Study Osun Drainage Basin, Southwestern Nigeria. Ife Journal of Science, 18(1): 177-201

Awoyemi, M. O.; Onyedim, G. C.; Arubayi, J. B. and Ariyibi, E. A. (2005). Influence of Lithology and Geological Structures on Drainage Patterns in Part of the Basement Complex Terrain of Southwestern Nigeria. Ife Journal of Science, 7(2), 291-296

Boesse, T. N. and Ocan, O. O. (1988). Geology and Evolution of the Ife-Ilesa Schist Belt, Southwestern Nigeria. Symposium on Benin-Nigeria Go-traverse of Proterozoic Geology and Tectonics of High Grade Terrains., 87-107

Conant, B. Jr. (2004). Delineating and Quantifying Groundwater Discharge Zones using Streambed Temperatures. Groundwater, 42(2): 243-257

De Swardt, A. M. J. (1953). The Geology of the Area around Ilesa. Geol.Surv.Nig.Bulletin 23

Elueze, A. A. (1977). Geological and Geochemical Studies in the Ilesa Schist Belt in relation to the Gold Mineralization. An Unpublished M. Phil. Thesis. University of Ibadan.

Freeze, R. A. and Witherspoon, P. A. (1967). Theoretical Analysis of Regional Groundwater Flow: 2. Effect of Water Table Configuration and Subsurface Permeability Variation. Water Resources Research, 4(2): 623-634

Harbaugh, A. W., Banta, E. R., Hill, M. C. and McDonald, M. G. (2002). The United States Geological Survey's Modular Groundwater Flow Model-User Guide to Modularization Concepts and the Groundwater Flow Process. USGS Open-File Report 00-92

Herman, G. C. (2005). Joints and Veins in the Newark Basin-View from the 21st Century. Field Guide and Proceedings. Editied by Gates, A. E. 75-117. Geological Association of New Jersey, Trenton.

Lacombe, P. J. (2000). Hydrogeologic framework, Water Level and Trichloroethylene Contamination. Naval Air Force Centre, West Trenton, New Jersey, 1993-97, USGS Water Resource Investigation Report, 98-4167

Mallast, U.; Gloaguen, R.; Geyer, S.; Rodiger, T. and Siebert, C. (2011). Semi-Authomatic Extraction of Lineaments from Remote Sensing Data and the Derivation of Groundwater Flowpaths. Hydrol.Earth Syst.Sci.Disc., 8, 1399-1431

Odeyemi, I .B., Anifowose, Y. B. and Asiwaju-Bello, Y. A. (1999). Multi-Technique Graphical Analyses of Fractures from Remote Sensing Images of Basement Regions of Nigeria. J.Min.Geol., 35(1), 9-21

Okunubi, M. O. and Olorunfemi, M. O. (2016). Integrated Geophysical Investigation of Remotely Sensed Suspected Fault Zones around Iwaraja-Ijebu Ijesa Area of Osun State, Nigeria. Ife Journal of Science, 18(1): 133-146.

Olorunfemi, M. O. (1990). The Hydrogeological Implication of Topographic Variation with Overburden Thickness in Basement Complex Area of Southwestern Nigeria. J.Min.Geol, 26(1).

Olorunfemi, M. O. and Fasuyi, S. A. (1993). Aquifer Types and the Geoelectric/Hydrogeologic Characteristics of Part of the Central Basement Terrain on Nigeria (Niger State). J.Afri.Earth, 16(3), 309-317 
Oluyide, P. O. (1988). Structural Trends in the Nigerian Basement Complex. In Oluyide, P. O., Mbonu, W. C., Ogezi, A. E., Egbuniwe, I. G., Ajibade, A. C., and Umeji, A. C. (Eds.): Precambrian Geology of Nigeria. Geol.Surv.Nigeria, $99-102$

Orabone, K. D. (1997). Fracture Patterns in the Passaic Formation near Piscataway, New Jersey: Their Effect on Groundwater Flow and Contaminant Migration. M.Sc. Thesis, Department of Geological Sciences, RutgersState University of New Jersey, New Brunswick.

Oseji, J. O. (2010). Determination of Groundwater Flow Direction at Emu and Ogume Kingdoms/Nigeria. IJRRAS, 5(3): 310-314

Oxtobee, J. P. A. and Novakowski, K. (2002). A Field Investigation of Groundwater/Surface Water Interaction in a Fractured Bedrock Environment. J.Hydro. 269: 169-193

Peter, M. K. and Kirk, R. (1998). Evaluation of Groundwater Flow Directions in a Heterogeneous Aquifer using the Colloidal Borescope. Advances in Environmental Research, 2(1): 12-23

Shao, J. L., Zhao, Z. Z., Cui, Y. L., Wang, R., Li, C. Q. and Yang, Q. Q. (2009). Application of Groundwater Modeling System to the Evaluation of Groundwater Resources in North China Plain. Resources Science, 313: 361-369

Solomon, D. K., Moore, G. K., Toran, L. E., Dreier, R. B. and McMaster, W. M. (1992). Status Report: A Hydrologic Framework for the Oak Ridge Reservation. Report ORNL/TM-12026, Environmental Science Division

Sophocleous, M. (2002). Interaction between Groundwater and Surface Water: The State of Science, Hydrogeologial Journal, 10(1): 52-67

Sudicky, E. A. (1986). A Natural Gradient Experiment on Solute Transport in a Sand Aquifer: Spatial Variability of Hydraulic Conductivity and its Role in the Dispersion Process. Water Resources Research, 22(13): 2069-2082

Sudicky, E. A., Gilliam, R. W. and Frind, E. O. (1985). Experimental Investigation of Solute Transport in Stratified Porous Media: The Non-Reactive Case. Water Resources Research, 21(7): 1035-1041

Sun, R. J. and Johnson, R. H. (1994). Regional Aquifer System Analysis Program of the United States Geological Survey, 1978-1992. USGS Circular 1099

Tiedeman, C. R., Goode, D. J. and Hsieh, P. A. (1998). Characterizing a Groundwater Basin in a New England Mountain and Valley Terrain. Groundwater, 36(4): 611620

Wang, L. Y., Han, J. P., Liu, J. R., Ye, C., Zheng, Y. J., Wan, L. Q., Li, W. P. and Zhou, Y. X. (2009). Modeling of Regional Groundwater Flow in Beijing Plain. Journal of Hydrogeology and Engineering Geology, 36(1): 1119

Woessner, W. M. (2000). Stream and Fluvial Plain groundwater Interactions: Rescaling Hydrogeologic Thought. Groundwater, 38(3): 423-429.
Ying, G. G., Toze, S., Hanna, J., Yu, X. Y., Dillon, P. J. and Kookana, R. S. (2008). Decay of EndocrineDisrupting Chemicals in Aerobic and Anoxic Groundwater. Water Resources, 42: 1133-1141. Doi:10.1016/j.watres.2007.08.029

Zhou, Y. and Li, W. (2011). A Review of Regional Groundwater Flow Modeling. Geoscience Frontiers, 2(2): $205-214$ 